\title{
Abstentions in 2014 and 2019 Indonesian elections: Case study of pro-democracy activists
}

\author{
M. Syaeful Anam ${ }^{1 *}$, Gumilar Rusliwa Somantri ${ }^{2}$ \\ ${ }^{1 \& 2}$ Department of Sociology, Universitas Indonesia, Indonesia \\ *Corresponding author \\ E-mail address: saiful.anam1308@gmail.com \\ DOI: https://doi.org/10.21107/sml.v3i1.7307
}

\begin{tabular}{|c|c|}
\hline Article Info & A BSTRACT \\
\hline $\begin{array}{l}\text { Keywords: } \\
\text { Abstentions } \\
\text { Pro-democracy } \\
\text { activists } \\
\text { Elections } \\
\text { Collective action } \\
\text { Contentious } \\
\text { politics }\end{array}$ & $\begin{array}{l}\text { This article discusses how the dynamics of the abstentions phenomenon } \\
\text { among pro-democracy activists in the 2014-2019 general election in Indonesia. } \\
\text { While pro-democracy activists have increasingly chosen "struggle within", } \\
\text { there are still critical groups that have voted for abstentions in 2014-2019 } \\
\text { general election. Charles Tilly's concept of collective action and contentious } \\
\text { politics is used in this study. This study uses a qualitative approach to the } \\
\text { type of case study research. Researchers explore data through in-depth } \\
\text { interviews as primary data and secondary data is extracted through library } \\
\text { research. The analysis is carried out with the abstractive inductive logic. } \\
\text { This research shows that abstentions are contentious collective actions. The } \\
\text { abstentions movement was born from a network of pro-democracy activists } \\
\text { who have been engaged in advocacy work. Abstentions carried out in protest } \\
\text { against the authorities and the boycott of the election. The boycott choice is } \\
\text { contentious politics. }\end{array}$ \\
\hline
\end{tabular}

Citation suggestion:

Anam, M. S., \& Somantri, G. R. (2020). Abstentions in 2014 and 2019 Indonesian elections: Case study of prodemocracy activists. Simulacra, 3(1), 27-42. https://doi.org/10.21107/sml.v3i1.7307

Received 18 May 2020; Received in revised form 28 May 2020; Accepted 2 June 2020; Published online 25 June 2020. 


\section{Introduction}

Abstentions as a political movement in a democratic climate, is considered highly necessary. The democratic system still needs and even fosters social movements. The democratic system itself does not guarantee economic distribution and access to justice to all (Amenta, 2005). Abstentions in all forms of articulation are also part of political participation. Huntington and Nelson (1980: 6) defined political participation as "citizen activities aimed at influencing government decision making."

The abstentions movement or Golput (golongan putih) first appeared in the 1971 Election and was led by Arief Budiman. The target of the abstentions movement at that time was the Golongan Karya Party (Golkar). The prefix 'gol-' on golput deliberately took the prefix of the Golkar Party name. Not just the name, the Golput logo also copied the Golkar party logo. The Golput propaganda logo also used a similar pentagon logo. However, the middle was blank and white (Heryanto, 2019). At that time, golput propaganda was disseminated in public places and with the slogan 'pick the white color.' That way, the vote could not be counted as a valid vote. The abstentions movement was also caused by the dominance of the authority, which was supported by the Indonesian Armed Forces (ABRI). The limitation of political parties as to the three main axes at that time was also seen as a barrier to democracy. In a structured, systematic and massive way, the authorities ensured victory for Golkar Party. As for Sanit (1992: 190), the abstentions movement was considered as an act of political protest based on national issues. The demands of the abstentions movement were aimed at the essence of the election as a medium to achieve the dream of independence.
The basis of the abstentions movement is 'protest' - criticism of the political behavior of politicians that harm the people, and considers alienation. The critical group plays an essential component of participation in a democratic society. This phenomenon is known as 'democracy from below.' The course of contemporary democracy is elite democracy, with elections as merely a fiveyear procedural political mechanism to maintain the circulation of elite groups. Elections should open the way for the betterment of life, as Lane (2014) stated. 'Democracy' and prosperity are seen as the same thing, and in many ways, for the people, both must be combined. Abstentions movements in Indonesia in the 2014 and 2019 elections could not be separated from democratic actors. Abstentions are defined as active and critical actions in assessing social and political events that occur.

There have been many studies of abstentions. Abstentions were defined as political expressions and resistance to the ruling regime (Obradovic-Wochnik and Wochnik 2014; Superti 2015; Superti 2016). Protests were made when the government in power was less than optimal in performance. Some scholars, such as Fachichini and Jaeck (2019) and Plane and Gershtenson (2004), focused their work more on the study of voter behavior by explaining the causes of abstentions' decisions. Abstentions were also expected when the existence of a political system and political parties carry more elite interests (Kang 2004; Birch and Dennison, 2017). Some research also stated that abstentions were chosen because the reality was getting further away from democratic ideals (Blais et al. 2019; Katz and Levin, 2018; Powert and Roberts, 1995). In addition, the reason for abstentions was also associated with political education, especially political knowledge and information (Feddenser and Pesendorfer, 1999; Almlund, 2018). 
This paper discussed the dynamics of the abstentions phenomenon among prodemocracy activists in the 2014 and 2019 General Elections in Indonesia. The dynamics of abstentions were reviewed through the thoughts of Charles Tilly (2008), ranging from collective action to contentious politics. Thus, this research could provide a complete understanding of the abstentions movement, namely as part of political participation and alternative paths of struggle in order to achieve a substantial democracy.

\section{Method}

This research used a qualitative approach to case study research. The study focused on the case studies of Abstentions in the Indonesian General Elections (2014 and 2019) which started from the case of Pro-Democracy Activists. Pro-democracy activists who were studied in the research were involved in the abstentions movement, whose primary campaign was 'SayaGolput.' The purpose of this study was to explore and understand the phenomenon of abstentions in the General Elections in Indonesia in greater depth.

Primary data were collected through in-depth interviews and secondary data in the form of a literature study related to abstentions. The informants in this study were the abstentions actors. These actors became key informants in the study and were selected using the purposive sampling method. Four informants were selected purposively. Then, the researcher got the other informant with the snowball method. Finally, the researchers found three more informants who contributed to the abstentions movement. Transcript and data coding was done using Nvivo 12 software. The data analysis approach used abstractive inductive logic from exclusive to general.

\section{Results and Discussion}

\section{Abstentions Movement in 2014-2019 General Election}

In the 2014 elections, abstentions movements were present to alternative voice narratives by progressive pro-democracy leftists. Abstentions movement were disseminated through the main channel of Komite Politik Alternatif (Alternative Political Committee). The main slogan at the time was "Lawan Pemilu 2014, Bangun Partai Alternatif!" (Opposing the 2014 Elections, Building an Alternative Party). The network was built by several organizations including KP SBGN, KP SGMK, SMI, GSPB, PPR, PPI, KPO PRP, FPBI, SBMI, Pembebasan, LIPS, PPBI Jatim, Mahardhika Mojokerto, SBM, Frontjak, Sebumi, GRI, and SPRI (Arahjuang. com, 2014). According to them, the candidates of the 2014 election were essentially the same. There were no candidates who provided answers to the real problems of the people. In addition, promises and welfare programs from political elites in the previous election also failed to be realized. Thus, there needed to be an alternative movement on a national scale with a firm attitude and position in the 2014 elections. The movement was expected to encourage the people's struggle. West Papua National Committee Abstentions (KNPB) also decided to abstain from the election. They stated that they would make no compromise with various products from the Indonesian colonial state. KNPB remained in the position of abstentions or did not participate in the 2014 elections. They did not compromise with any programs carried out by the Republic of Indonesia, especially the presidential election (Suarapapua.com, 2014).

There were three main ideas presented by the Alternative Politics Committee. First, the 2014 election did not favor the people because of the absence vision and program 
that favors the people and brings alternative politics to the candidates. Second, democracy had not been sufficiently implemented. As a result, elections did not lead to the transformation of people's lives. Third, the alternative party vision indeed presented alternative programs that favor the people. Fourth, the alternative party appealed and invited all people's movement to unite and position themselves as the foundation for the development of an alternative party. Fifth, the alternative party appealed and invited all Indonesians who have a historical awareness of the people's struggle to join an alternative movement (Arahjuang.com, 2014).

Abstentions were also prevalent in the 2019 elections. The abstentions in 2019 election attracted plenty of attention, as was the case when Arief Budiman launched Kelompok Putih (White Group) in 1971. In the 2019 elections, the collective action of abstentions was synthesized in the SayaGolput movement. The SayaGolput Movement consisted of a diverse ideological spectrum. Quoted from the information on the Medium platform, SayaGolput was a citizenship movement that decides to 'vote not to vote.' Voting to be absent was an attempt to return to a more substantial democracy. SayaGolput movement was explained in their manifesto called 'Kertas Putih Golongan Putih 2019' (White Paper of the 2019 White Group) in which they declared that the people had no choice in the 2019 elections. In the current political system, the opportunity for the emergence of propeople candidates was almost impossible. The big capitalists determined the choice. The alliance consisted of oligarchs, who worked with candidates through political and money transactions. Then, after the election, there would be a division of power. Both Jokowi and Prabowo were elites who were part of the mining, plantation, natural resource, and media bandits. Both candidates were supported by oligarchs and generals who have violated human rights. In the context of the 2019 elections, there was a war of discourse as disagreements about abstentions emerged the media.

\section{Pro-Democracy Activists' Vote Not to Vote}

The reality of abstentions in prodemocracy circles can be understood as a protest movement. The abstentions movement in the 2019 election was composed of urban intellectuals and activists in various sectors who gathered themselves in a movement that was not formally organized but had organizational principles, ideologies, action programs, and group agendas. It has similar aspiration as it was first coined in 1971, which was to establish democracy in all aspects of people's lives. That spirit also made pro-democracy activists voted not to vote (abstentions) in the 2019 elections. There was a clear line between formal liberal democracy, on the one hand, and participatory democracy that was more substantive on the other. The most minimal conventional definition tended to be limiting as a political system, which was different from the economic and social system. Uhlin (1998) defined democratization as an encompassing social and economic life.

Tilly (1978) developed an analysis to understand the collective actions of civil organizations in the events of the revolution and political dissent in Britain and the United States in the 18th century. The model consisted of state-making, interest, organization, and collective action. State making was described as a political situation that is faced and interpreted into a political program. The organization looks at the problems that exist within the organization. Mobilization is a choice of political strategy. Collective action is a tactical action carried out. The state-making situation determines the shape of the interest and organization. 
Abstentions became a collective action in the 2019 elections when the people were faced with a situation of government policies that increasingly did not provide transformation to the lives of many people.

In the Jokowi Government, democracy became an amplifier to choose abstentions. Democracy was carried out with threats and fears, such as criminal threats to abstentions group, deaths because of expressing opinions, and restrictions on demonstrations. Transparency during the reformation period could not be considered as a form of commitment to human rights. Democracy was only carried out at a minimum level as a mere political tactic or requirement.

Control of the critical group was carried out in various ways, such as utilizing the network of former NGOs within the government, the use of buzzers, and negative labeling to critical groups. Meanwhile, Alghiffari Aqsa (01/22/2020) considered the Jokowi's rule as a bleak period in the rule of law because politics and investment were placed above the law. He also added that Jokowi's promise to fulfill the human rights in the 2014 election was also not implemented. Instead, government policies increased the number of cases of human rights violations in Indonesia. Government rhetoric regarding diversity and tolerance was also questioned because the government took no action to resolve conflicts over houses of worship. Protection of minorities was only a false promise because harassments against vulnerable groups such as LGBT went unpunished by the state.

Lini (01/26/2020) added that economic liberalization by Jokowi encouraged policies that were centered on the investors' interests. The alignments resulted in the marginalization of the people as the highest sovereign owner. Therefore, it is not surprising that many agrarian conflicts occurred where people's lands were displaced by development agendas.
The Jokowi-style development ideology also sacrificed several other sectors. Farid Gaban (02/13/2020) revealed that Jokowi's first period was focused on infrastructure and had no impact on aspects of human development. Developments were carried out by damaging the environment and often displacing people who should have been the subject of development. The imagination of human development through Mental Revolution was ignored. The trajectory of Indonesian development ideology postreformation period still revolved around Soeharto's imagination of development. Suharto ran a Development Trilogy which contained three programs, namely economic growth, political stability, and income distribution (Budiman and Tornquist, 2001). Economic growth was supported by attracting as much investment as possible. One of the boosted investment sectors was the extractive sector. This policy caused massive destruction of nature in the reform era, especially in Jokowi era. The reluctance of some pro-democracy activists to enter the system as chosen by several other prodemocracy groups is due to the failure of pro-democracy groups.

The choice of critical engagement by some pro-democracy groups, in fact, also did not make a significant change. Jokowi's policies that were not in line with the democratic agenda and advocacy of pro-democracy activists were what drove protests against power by abstentions. Election as the formation of legitimacy was protested because substantial democracy has not yet been fulfilled. It should have sparked a transformation of public life, especially in the weak urban group, displaced farmers, exploited workers, vulnerable groups, and minorities. Such a situation revealed that the state markers were far from being partial to the people. In Sanit's (1992) view, the abstention was categorized as an effort to protest the process of meeting the needs 
of the Indonesian political system, which was seen as not operating the development of democracy. Likewise, apathetic nonideological abstentions occur when daily politics do not bring benefits to people's daily lives. The statement was delivered by Alghiffari Aqsa (01/22/2020) in the following interview excerpt:

"In my opinion, apathy is also ideological. When people do not want to vote because they feel that their votes were useless, then actually if we retrace it, there is a disconnection between the election and the political system with the daily lives of citizens."

On the one hand, the speed of development in the Jokowi period led to an increase in output in the form of national production or income. On the other hand, social inequalities due to differences in abilities and opportunities between groups of people also widen throughout the development. It seems that the decreasing number of people experiencing absolute poverty did not prevent the speed of wealth growth of the society's middle and upper classes. The disappointment of prodemocracy activists for development was also caused by the impact of government projects and the expansion of the business world on land and labor issues. Land acquisition for government and private projects brought new problems related to compensation and loss of livelihoods. The problem arouses those who experience it directly and those who follow it with assistance or advocacy work. The same concerns also occur in the world of work between employers and workers. Various problems that occurred were related to the issue of workers' wages, workers' protection, and policies that harm other workers in many companies. These problems cannot necessarily be solved through election policy by selecting available candidates.

Reflecting on the struggle agenda that affect various sectors, the abstentions movement in the 2019 Elections could reach influence ideological spectrums of pro-democracy activists. Even so, the prodemocracy activist acted as an individual rather than as an organization. This was revealed by the Chairperson of YLBHI, Asfinawati (17/01/2020):

"So, we are indeed organizationally impossible to be abstentions because those who have the right to vote are individuals. However, we see organizationally, and people must have the right to freedom of politics, including not to vote. The narratives at that time (from the government) were New Order narratives which stated "choosing is rights and obligations" and that was expressed by Mr Wiranto."

In addition, abstentions were raised as the third group, which was positioned as a buffer to break the rigours of polarization that caused a stir in the community. Even so, the main factor remained the distrust of the competency of the candidates and existing political parties. The available data showed that the commitment of the two candidates for human rights was equally bad. Reports released by KontraS (2019) revealed that the Generals supporting both candidates had human rights violation track records. Another problem was the strength of the mining oligarchy in both Jokowi and Prabowo group, which was opened by research findings from Jatam (2018).

Other criticisms were also directed to political parties. Political parties were considered not representing the interests of the people. Alghiffari Aqsa (01/22/2020) believed that the problem of democracy in Indonesia as being filled with actors who 
were not democrats and were not committed to democracy. These actors were not drivers of change, but pro-status quo. The quality of democracy decreased when development did not involve citizens' active participation. People were 'forced' to follow the authorities' agendas.

As a movement, Golput 2019 set the platform and agenda of its struggle in the Kertas Putih Golput document. The agenda of the struggle departed from the aspect of interest on the advocated issues, aspects of the organization relating to the similarity of attitudes, and concrete experiences when dealing with the Jokowi regime. These aspects were taken into consideration in formulating the 2019 Golput struggle agenda. The agenda of the struggle was a manifesto of issues and avocation that were being and continue to be fought by pro-democracy activists. These issues included welfare for the people, agrarian affairs, living space and environment, labor and employment, anticorruption, militarism and military politics, agenda of fulfilling human rights, vulnerable and minority groups, the future of Papua, improvement of the political system, and law and justice reform as an effective recovery institution.

The struggle agenda were illustrated in the distribution of ideological and advocacy groups of pro-democracy activists who formed the 2019 abstentions movement. These concerns departed from the real situation of advocacy carried out by civil society groups. The sectors included the agrarian sector and spatial planning, environment, human rights, law and anti-corruption, labour, to vulnerable groups and minorities. They were the voice of groups marginalized by the country's development agenda. This protest movement also illustrated the form of shifting coalition from civil society groups with a different spectrum of movements and ideologies. The coalition took place when pro-democracy elements began to find stagnation in the advocacy of the struggle.

On the other hand, the stagnation came from the same opponent, namely "the government and the elite." Jokowi's government had become an obstacle in advancing democratic agendas championed by several civil society groups. It could be said that the regime was a common enemy. The form of motion taken was more fluid and dynamic. There was no formalization of being an organization. In Asfinawati's view (01/17/2020), this new social movement no longer had a particular leadership structure, unlike the old paradigm. Learning from previous movements, the presence of structure brought up the characterizations in the movement. The figuration of a movement actually would cause a paradox in the body of the movement. Often, the success achieved by a movement was seen as an individual or figure of achievement. The rejection of the characterization was also confirmed by Farid Gaban (02/13/2020):

"I think everyone is well aware. We do not want to rely on characters. We rely on systems, systemic changes. Who I am or Dandhy is not important. But what can we do for a change."

Theabstentions movementalsoillustrates the future of a fluid social movement, without leadership and barriers, and all can be involved. It is different when in the New Order era when the movement was so centralized and structured. Collective action can occur because it has almost the same concrete experience. Lini Zurlia (26/01/2020), a Purplecode activist, tells the story of the process of crystallizing the abstentions movement:

"Collectively, because of mutual knowledge of individuals advocating, their political choices are increasingly visible. Then, these 
individuals network, communicate, meet and discuss. Then, the manifestations of the discussions were born."

Bilven (01/20/2020) also viewed that this collective action could be formed because it had the same demands: united by distrust of the existing democratic system. Elisa Sutanudjaja (02/19/2020) analogized that the system had been damaged. Democracy has not sparked the transformation of public life, with the tenth indicator of the 2019 Golput struggle agenda. Pro-democracy activists interpreted democracy as not merely voting in elections. 'Substantial' democracy became a meeting point for abstentions activists.

"If that seems like the ideology is not too significant. What is significant is that it only encourages democratization. So, ideology is democracy. The ideology of democracy is substantial. What should be from the people, by the people, for the people but from the oligarchy, by the oligarchy, for the oligarchy? People only get their votes were taken" (Bilven, 01/20/2020).

These elements are joined on behalf of individuals, not organizations. Some organizations also declared abstentions in 2019. However, Alghiffari Aqsa (01/22/2020) said that if an organization facilitates, then activates, and mobilizes all its resources for the coalition, then it can be said that the institution also supports the work of the Golput movement. The Golput collective action succeeded in uniting various elements of the movement. This condition can occur because:

"There is a common enemy. This is a group that is increasingly pressured by the state, like the political elite. Inevitably have to join. If not, who will help? Including trade unions that were fragmented, can be merged, united. The attitude of the KASBI organization is abstention" (Alghiffari Aqsa, 01/22/2020).
In addition, the consolidation of a small people's movements carried out at each point saw its political momentum, the 2019 Election. There was room for the movement to enter the arena of contestation of discourse. On the one hand, this was a weak point of abstentions. Because the network was informal, the advocacy for the movement was also based on momentum. When the momentum was all used up, the abstentions movement also disappeared. Thus, there was no continuation of the movement. The interesting thing about this condition was that the absence of organization did not become a barrier in the world of activism. Bennet and Segerberg (2013) synthesized this activism in the framework of "connective action." There are three main characteristics of connective action. First, cyberspace political participation in the logic of connective action is different from classical logic. Second, in today's digital world, political participation is more like an individual's personal expression than a group action. Third, communication networks become the core of organizing in cyberspace and replace the leadership and membership hierarchies.

Abstentions can be seen as a reference attitude when dealing with the implementation of democratic principles. Abstentions in elections are an estuary for critical attitudes and disappointment or dissatisfaction of the citizens of the political process they experience or feel. Abstentions become the choice for those who have a clear picture of the obstacles to the development of democracy in political life. They understood the function of the election towards the creation of the legitimacy of the political system. This was revealed by Asfinawati (17/01/2020):

"When the government is powerful (absolute), the bargaining power must be high. So the authoritarian regimes always try to arrange elections, so he says, I have $80 \%$, 
90\% legitimacy. Therefore I am keen if I want to do anything. So at least, if we can show that not all people can not be fooled like that. That is the short-term goal (abstentions)."

Therefore, they knowingly exercised their right not to vote without following applicable regulations to cancel their vote to election contestants by abstentions, whether by coming to the polling station or not (Sanit, 1992).

\section{Abstentions Movement: from Collective Action to Contentious Politics}

Collective action is a combination
of various interests, organizations, mobilization, and opportunities that have dynamics (Tilly, 1978). The interests in the abstentions movement are manifested in 10 agendas of struggle. This demand stems from the vision of movement actors who are already involved in advocacy work. Abstentions were chosen as a rational way to fight authoritarian regimes or those who were in power. Abstentions are the closest expression of protest. This collective action was carried out as an effort to restore the true meaning of democracy. Collective action itself has a variety of forms that can be short or long-term, institutionalized or confusing, boring, dull or dramatic.

Political opportunity (opportunity) became an essential element for the movement. Political opportunities can consist of a degree of openness, elite stability, elite groupings and divisions, and repressive actions. Opportunities and threats or political situations are taken into account in the movement because a reading of situations of tension and politics must look at social control activities carried out by the opposing party. This situation is referred to as the repertoire of contentious. Abstentions are in a more open post-reform political situation. However, there is a separate note in the implementation of political democracy, especially during President Jokowi. During the Jokowi period, fears of critical groups also arose. The situation was experienced by the 2019 abstentions movement in the form of criminal threats for abstentions movers. The discourse certainly violates the right to freedom of opinion that should be guaranteed by the state. The climate of democracy requires political democracy. Political democracy in the presidential election is in the form of the right not to vote. The act of repression is not only done by 'countries' but also by buzzers. The buzzers are used to attack people or critical groups on social media.

Political opportunities and the power of resource mobilization influence the tactics and strategies of the 2019 abstentions movement. Digital media has room to fill the lack of resources and increasingly limited political dynamics to mobilize a more extensive mass. In some instances, the mobilization of the digital world is used as a social movement strategy. The Arab Spring that swept Tunisia, Egypt to Syria, the Umbrella Revolution in Hong Kong, to acts of terrorism commanded by ISIS in various parts of the world is an example. The form of mobilization also varies, from spontaneous actions without command such as Occupy Wall Street, decentralized transnational networks such as Women's March, to actions led by activists and NGOs like Earth Hour and calls for climate change. Social media also disrupts social movements. In the 2019 elections, the pro-democracy activist group Golput movement used social media as a propaganda tool.

The use of social media is filled with abstentions opinion. This was done given the increasingly limited mainstream media to provide space for opinion for abstentions because the media, in general, framed more fear of abstentions. Media in Indonesia mostly operates in the spirit of a free market 
where news production is determined by the audience and readers. Increased concentration and media conglomerates in Indonesia also play a substantial role and are played by owners by limiting information. According to Robinson and Hadiz (2004), although the authoritarian government has ended, the era of democracy in Indonesia since 1998 has been dominated by oligarchic powers. Winters (2011) explains that oligarchs are actors who govern and control material resources on a massive scale that can be used to maintain or expand personal wealth and privileged social positions.

The power of the oligarchy also controls the media sector. For Tapsell (2018), first, the media oligarchs generally produce news and information as they wish. The same thing was said by Winters if the media were controlled by the same actors and political forces, it was almost impossible that a critical party or free press would provide space to challenge these forms of oligarchic domination. Second, as a result, candidates who run in elections must buy access to the media, which in some cases means buying $\mathrm{TV}$, radio and newspapers at the same time. These conditions make oligarchic forces frame debate and discourse in the public sphere. The debate arose due to the clash between the figures from the oligarch and the political groups that controlled these media.

Efforts to mobilize other masses can be in the form of promoting campaigns on social media. Abstentions campaigns on social media could be seen from the main tagline, \#SayaGolput, which also filled the Twitter trending topic. In addition, the use of the SayaGolput profile was also massive in social media, such as Facebook, Twitter, Instagram. It fought over discourse along with the massive campaign of presidential candidates 01 and 02. Drone Emprit (2019) reviewed the dynamics of the topic of conversation about abstentions on Twitter. The performance of the first debate became the start of the rise of abstentions, followed by the pros and cons debate that accompanied it. Then, the discourse on the release of Abu Bakar Baasyir also affected the issues surrounding abstentions. The appearance of the Dildo account on Instagram was also suspected by anti-abstentions groups. When looking at these conditions, the abstentions group at least managed to frame abstentions discourse on social media. The fear narrative raised by the two candidates was that the emergence of abstentions in favor of conservatives and deemed unpatriotic.

The emergence of influencers and central figures engaged in the activism sector boosted abstentions in 2019. When they did something, it indeed increased the framing of the abstentions movement. Integrally, they are known for their support for groups that were marginalized and removed by the state. Ideas as an argument for abstentions and counter-narratives against anti-abstentions were also widely written through alternative channels such as Medium, Indoprogress, Sorge Magazine and other online media. The increased escalation of abstentions campaigns on social media had also increased attacks on abstentions. It also made the exposures to the 2019 abstentions movement to increase. The massive abstentions movement is due to the increasingly consolidated pro-democracy forces that were initially scattered since 2018 (Bilven, 01/20/2020). Even if reflecting on the election results, the number of abstentions had decreased compared to the previous elections, the reverberations of the abstentions grew in 2019. That was because the abstentions campaign was a collective movement. Thus, the collectivities complement each other (Lini Zurlia, 01/26/2020).

The massive discourse of abstentions makes several parties not remain silent. A counter-movement emerged from the regime 
and the pro-status quo group. Counter movements were carried out to maintain political structures and influence society. These conditions position the abstentions movement to be a challenger for the regime, the elite, the regime and its cronies to become members (incumbent). Both were trying to build claims and try to influence society and build coalitions. The difference was, the abstentions movement built mobilization for protest, networking among civil society groups to consolidate critical groups, and attract the sympathy of the wider community. Meanwhile, the regime and its networks mutually consolidated the elite ranks made repressive statements and encouraged counter-abstention intellectual elements along with government institutions to campaign for anti-abstention.

Public officials encouraged the public to exercise their voting rights in the 2019 elections. The use of voting rights was called a form of nationalism and patriotism. Calls for non-abstention were spread in significant media and social media. On social media, the campaign not to abstain also filled the social media discourse. Based on Drone Emprit's data, Ismail Fahmi's social media analysis tool, it was revealed that issues related to abstentions were more often discussed by incumbent supporters. Meanwhile, the Ahok topic contributed 31 per cent of the total volume of abstentions. In the runup to Ahok's freedom, the appeal of 'don't abstain,' was echoed again. The anti-absent dialectics was centralized on two accounts, namely @budimandjatmiko, PDIP politician and @fajrinamaya, who were Jokowi's supporters. The government itself was also trying to suppress abstentions. President Jokowi signed the Presidential Instruction No. 7 of 2019 concerning 2018-2019 State Defending Action Plan. One crucial point in the president's instructions was the view that states abstentions were a genuine threat to the state. The call not to abstain was delivered by many KPU, TNI and Polri institutions. Banners were distributed in many places which contained appeals to vote.

The call for abstentions was also conveyed by intellectuals. Mahfud MD and Romo Magniz were figures who often called for the use of the right to vote. According to both, choosing was an effort to prevent the worst in power, the lesser evil. Religious organizations also called for not abstentions. MUI even forbids abstentions. Meanwhile, NU-Muhammadiyah also called on its members to exercise their right to vote in the 2019 Election. Strong sentiments towards abstentions were called upon by the incumbents. According to Wiranto, the abstentions were an act of mischief (Kompas, 2019), while Megawati called abstentions as cowards (Detik, 2019). KPU Chair Arief Budiman stressed that inviting non-voters was not allowed. The Head of Public Information of the Police Public Relations Division added the use of electronic media to promote abstentions could be subject to ITE Law. For the National Campaign Team, the 02 teams did not agree to charge abstentions with the ITE Law. Abstentions must be opposed with ideas. Narratives to encourage voting were also conveyed by influencers and artists. Slank and Iwan Falls were two musicians calling for abstentions in 2019.

The existence of threats and opposition from these opponents actually led to the abstentions movement, which was previously a collective action, turned into an act of resistance. According to Tilly (1978), these changes occur because social movements interact with the contentious environment (repertoire contentious) and the availability of supporting factors such as the existence of supporting resources, coalition groups, and support of other potential resources such as pressure and organizing efforts. This opportunity was supported by the division of the political elite in groups 01 and group 02, which were fighting for votes. Thus, 
it was beneficial because it would make each group careful in behaving and issuing policies for incumbents. This was evident that in Prabowo's group, sentiment towards abstentions was not adverse. The power of abstentions was also formed by ideological views related to democracy. This was reflected in the agenda of encouraging alternative politics. Ideology was positioned as the basis for the accumulation of abstentions activist resources. The collectivity was advantageous for the mobilization of collective action, given that the elements of the abstentions movement were composed of cross-sector activists and organizations.

Abstentions, even though their presence was just momentum, can provide contentious politics which quite disturbs national politics. Resistance protests can last long, up and down. Coalitions do not have to be permanent, and sometimes differences occur among social movements. That happened at the 2019 abstentions movement. The abstentions took place during the 2019 Elections, but the dynamic coalition was also present in the post-2019 momentum. Prodemocracy activists who were members of the 2019 abstentions movement were also involved in other protest movements such as the Corruption Reformation, to the action of rejecting Omnibus Law. The socio-political ties can last until the goals of the movement were reached, and the opponent provides opportunities for change.

Reflecting from Tarrow's (1998) theorist, the abstentions can be called a politics of resistance. As for Tilly (2008), the form of abstentions as an election boycott is a disruptive technique of contentious politics. Political opposition occurs when pro-democracy activists perceive the advancement of democratic agendas as being hampered by the existing political structures and systems. Political democracy is considered increasingly backward, as is the case with social and economic democracy, which increasingly does not provide transformation to people's lives. The target of these demands is addressed to the authorities and elites who benefit from today's democratic climate. The abstentions movement is an effort to confront opponents, elites and rulers.

There were several confrontations by the abstentions groups, including the following:

\section{Demonstration}

Some abstentions expressed their attitude by holding demonstrations. Demonstrations were carried out in several cities such as Jakarta, North Maluku, Palu and Lampung. In Jakarta, one of the mass demonstrators expressed their attitude in front of the General Election Commission's office. The mass actions of the Alternative Party Committee demanded that the democratic space be expanded in Indonesia. The mass of the action consisted of various organizations, including the People's Workers' Party (PRP), the Central Workers' National Movement (SGBN), the Indonesian People's Movement Confederation (KPRI), the Indonesian Political Congress (KPO), and the National Union Confederation (KSN). On Thursday, February 21, 2019, dozens of people also staged a rally by gathering in the Aspiration Park opposite the State Palace. A white banner depicting the palm with the words "I Am Absent" was stretched. They voiced their political choices in the 2019 elections by choosing not to vote for abstentions (Kumparan, 2019).

\section{Discussion Series}

The abstentions movement also held discussions in various big cities. In Jakarta, the centre for discussion activities was in the YLBHI building. Several discussion agendas were held as a meeting point for ideas and informal consolidation of movements. 
On August 31, 2018, a discussion with the theme "How We Respond Abstentions" was held. Discussions brought together pro-democracy circles both pros and cons of abstentions. Information channel about abstentions discussion was updated via social media, SayaGolput on Twitter, Facebook and Instagram. A few days before the voting day, a community gathering was held. The event was held on Saturday, April 13, 2019, at the YLBHI building. The event began with a press conference and abstentions declaration on April 17, 2019. The press release explained that the abstentions were an independent political intersection encompassing agrarian and environmentalism, anti-corruption, militarism, labor rights, human rights, legal reform and judicial institutions. Discussions about abstentions were also held on many campuses. At UGM, for example, MAP Corner-MKP Club discussed the issue of Abstentions and the Future of Indonesian Democracy.

\section{Press Conference}

Abstentions activists also held several press conference agendas. One of the primary momenta was through the press conference "Abstentions are our rights". Civil society coalition consisting of the Indonesian Legal Aid Foundation (YLBHI), Lokataru, the Indonesian Legal Aid Association (PBHI), LBH Jakarta, the Commission for Missing Persons and Violence (KontraS), the Institute for Criminal Justice Reform (ICJR), LBH Society, conveying abstentions or not voting during elections was the right of every citizen. In the article Right to Abstentions (2019) released by SayaGolput, it explains that the right to vote and be elected as part of human rights, regulated in the 1945 Constitution, Article 28D paragraph 3, Human Rights Law, Article 23 paragraph 1 and the International Covenant on Rights Civil and Politics,
Article 25. In addition, Indonesia was also not a country that implements a compulsory voting system (requires voting).

\section{"Sexy Killers" Film}

The film "Sexy Killers" also filled the dynamics of the debate about abstentions, even though this film did not call for abstentions. However, this film was made by activists' abstentions. This was acknowledged by Roy Murtadho (02/18/2020):

\begin{abstract}
"That includes the abstentions agenda that makes Sexy Killers. At that time, there was me, and there was Merah (Jatam), Dandhy (Watchdoc). We are gang up on making film projects. That (so that) the community knows the power structure in Indonesia, who, which class was actually dominant and has surrounded the entire national agenda ".
\end{abstract}

\section{\#SayaGolput Propaganda}

Social media was also used to mobilize the 2019 abstentions movement. The primary hashtag that was echoed was \#SayaGolput. \#SayaGolput was distributed on Twitter, Facebook and Instagram. In addition to \#SayaGolput propaganda, simultaneous actions were also taken using the \#SayaGolput profile photo. The hashtag diverts attention between the massive discourse of war 01 and 02 on social media. The hashtag illustrates the activism of abstentions that was liquid, flexible, and not binding because it was carried out personally, but was connected by a shared concern about the abstentions of abstentions being echoed. The narration allows all people to be involved as people who have the same political preferences, who position themselves as people who are disadvantaged by the status quo and want the presence of change. 


\section{Concurrent Abstentions Action}

The final action of abstentions was abstentions in the 2019 elections. Abstentions can be done in two ways, first by damaging the ballot paper; second by not being present at the polling station (TPS). The number of abstentions (not voting) in the 2019 elections was around 19 per cent. Invalid ballots had also increased. Of the total valid votes of $154,257,601$, there was an invalid number of votes that reached $3,754,905$ or around $2.37 \%$ of the total valid votes in the Presidential Election (Pilpres). Meanwhile, in the Legislative Election (Pileg) there were $17,503,953$ or four times the number of invalid ballots in the Presidential Election. The number of legitimate votes for Pileg was 139,971,260 (rumahpemilu.org, 2019).

\section{Conclusion}

The abstentions movement in 2019 was driven by a group of pro-democracy activists who networked and shared the same concerns. These concerns arose from the real situation of advocacy work carried out by civil society groups. There were agrarian and spatial sectors, environment, human rights, law and anti-corruption, labor, to vulnerable groups and minorities: voices from groups marginalized by the country's development agenda. This protest movement also illustrated in the form of shifting coalition (liquid coalition) from civil society groups with a different spectrum of movements and ideologies. The coalition took place when pro-democracy elements began to find stagnation in the advocacy of the struggle. On the other hand, the stagnation comes from the same opponent, namely "the government and the elite".

Abstentions were acts of resistance that characterized contentious politics. In the view of pro-democracy activists, abstentions were a form of boycotting the election. This choice occurred because the agendas in promoting democracy were hampered by the existing political structures and systems. Political democracy was in decline. Meanwhile, the social and economic democracy that was being carried out did not provide transformation to people's lives. The protest movement was aimed at the authorities and elites who benefit from the current climate of democracy. The boycott movement by means of abstentions was an attempt to confront opponents, elites and rulers. The choice of pro-democracy by activists was of course to realize substantial democracy, which as aspired to in the ten demands in the 2019 Kertas Putih Golput.

\section{Declaration of Ownership}

This article is our original work.

\section{Conflict of Interest}

There is no conflict of interest to declare in this article.

\section{Ethical Clearance}

This study was approved by the institution.

\section{References}

Almlund, P. (2018). Non-voting young people in conflict with the political system. Journal of Political Power, 11(2), 230-251. https://doi.org/10.1080/215837 9X.2018.1477630

Amenta, E. (2005). Political context, challenger strategies, and mobilization: Explaining the impact of the Thownsend Plan. In D. S. Meyer, V. Jennes \& H. M. Ingram (eds.), Routing the opposition: Social movement, public policy and democracy. The University of Minnasota Press.

Arahjuang (2014). Komitepolitikalternatiflawan pemilu 2014: Bangun partai alternative. (http://www.arahjuang.com/2014/03/11/ 
komite-politik-alternatif-lawan-pemilu2014-bangun-partai-alternatif/), accessed in 10 April 2020.

Buehler, M. (2007). Local elite reconfiguration in post-new order Indonesia: The 2005 election of district government heads in South Sulawesi. Review of Indonesian and Malaysian Affairs, 40(1), 119-147.

Bennet, W. L., \& Segerberg, A. (2013). The logic of connective action: Digital media and the personalization of contentious politics. Cambridge University Press.

Birch, S., \& Dennison, J. (2019). How protest voters choose. Party Politics, 25(2), 110-125. https://doi. org/10.1177/1354068817698857

Blais, A., et.al. (2019). Was my decision to vote (or abstain) the right one? Party Politics, 25(3), 382-389. https://doi. org/10.1177/1354068817722058

Budiman, A., \& Tornquist, O., (eds.). (2001). Aktor demokrasi: Catatan tentang gerakan perlawanan di Indonesia. ISAI (Institut Arus Studi Informasi).

Detik. (2019). Megawati yang golput itu pengecut, tak usah jadi WNI. (https:// new s.detik.com/berita-jawatengah/d-4491225/megawati-yanggolput-itu-pengecut-tak-usah-jadi-wni), accessed in 29 February 2019.

Drone Emprit. (2019). Politik di media social. LP3ES Jakarta.

Facchini, F., \& Jaeck, L. (2019). Ideology and the rationality of non-voting. Rationality and Society, 12(1), 1-22. https://doi. org/10.1177/1043463119841033

Feddersen, T. J., \& Pesendorfer, W. (1999). Abstention in elections with asymmetric information and diverse preferences. American Political Science Review, 93(2), 381-298.

Heryanto, A. (2019). Setengah abad golput. Tempo.
Huntington, S. P., \& Nelson, J. (1980). Partisipasi politik di negara berkembang. Rineka Cipta.

Jackson, K. D., \& Pye, L. W. (1978). Political power and communication in Indonesia. University of California Press.

Jatam. (2019). Oligarki tambang di balik pilpres 2019, (https://www.jatam. org/2019/03/20/oligarki-tambang-dibalik-pilpres-2019/), accessed in 16 October 2019.

Kang, W. (2004). Protest voting and abstention under plurality rule elections: An alternative public choice approach. Journal of Theoretical Politics, 16(1), 79-102. https://doi. org/10.1177/0951629804038903

Katz, G., \& Levin, I. (2018). A general model of abstention under compulsory voting. Political Science Research and Methods, 6(3), 589-508. https://doi.org/10.1017/ psrm.2016.49

Kompas, (2019). Wiranto ingatkan mereka yang mengajak golput pada pemilu 2019. (https://nasional.kompas.com/ $\mathrm{read} / 2019 / 03 / 27 / 15473811 / \mathrm{wiranto}-$ ingatkan-mereka-yang-mengajakgolput-pada-pemilu-2019), accessed in 29 February 2020.

Kumparan. (2019). Golput yang tak pernah redup. (https://kumparan.com/ kumparannews/golput-yang-takpernah-redup-1549259580724886695), accessed in 10 April 2020.

Magnis-Suseno, F. (2019). Golput. Kompas, 12 Maret.

Lane, M. (2014). Unfinished nation. Djaman Baroe.

Mietzner, M. (2009). Indonesia's 2009 elections: Populism, dynasties and consolidation of the party system. Lowy Institute.

Mietzner, M., \& Aspinall, E. (2010). Problems of democratization in Indonesia: An overview. In E. Aspinall \& M. Mietzner 
(eds.), Problem of democratization in Indonesia: Elections institutions and society. ISEAS.

Obradovic-Wochnik, J., \& Wochnik, A. (2014). Invalid ballots and the "crisis of representative democracy": Reinventing protest at the 2012 Serbian elections. East European Politics and Societes and Cultures, 20(10), 1-28. https:// doi.org/10.1177/0888325414547430

Plane, D. L., \& Gershtenson, J. (2004). Candidates' ideological locations, abstention, and turnout in the U.S. midterm senate elections. Political Behavior, 26(1), 69-93. https://doi. org/10.1023/B:POBE.0000022344.05382. b4

Power, T. J., \& Robert, J. T. (1995). Compulsory voting invalid ballots, and abstention in Brazil. Political Research Quaterly, 48(3), 135-156. https://doi. org/10.1177/106591299504800407

Ricklefs, M. C. (2008). Sejarah Indonesia modern 1200-2008. Serambi Ilmu Semesta.

Robinson, R., \& Hadiz, V. R. (2004). Reorganizing power in Indonesia: The politics of oligarchy in an age of market. Routledge.

Rumah Pemilu. (2019). KPU tetapkan hasil perolehan suara, angka tidak sah pada pileg tinggi. (https://rumahpemilu.org/kputetapkan-hasil-perolehan-suara-angkasuara-tidak-sah-pada-pileg-tinggi/), accessed in 10 May 2020.

Sanit, A. (1992). Golput: Aneka pandangan dan fenomena politik. Pustaka Sinar Harapan.

Suara Papua. (2013). KNPB: Kami golput pada pemilu 2014. (https://suarapapua. com/2013/08/07/knpb-kami-golputpada-pemilu-2014/), accessed in 10 April 2020.

Superti, C. (2015). Vanguard of discontent: Comparing individual blank voting, mobilized protest voting, and voting abstention. Harvard University Press.

(2016). The blank and null vote: An alternative form of democratic protest? Harvard University Press.

Tapsell, R. (2018) Kuasa media di Indonesia: Kaum oligarki, warga dan revolusi digital. Marjin Kiri.

Tarrow, S. G. (1998). Power in movement. Cambridge University Press.

Tilly, C. (1978). From mobilization to revolution. University of Michigan.

(2004). Social movements: 1768-2004. Paradigm Publishers.

Tirto. (2019). KontraS catat 17 purnawirawan terlibat pelanggaran ham di masa lalu. (https://tirto.id/kontras-catat-17purnawirawan-terlibat-pelanggaranham-di-masa-lalu-dlWz), accessed in 16 October 2019.

Uhlin, A. (1997). Oposisi berserak: Arus deras demokratisasi gelombang ketiga di Indonesia. Mizan.

Winters, J. A. (2011). Oligarchy and democracy. The American Interest, 2(2), 18-27.

Yuniarti, S. (2009). Golput dan pemilu di Indonesia. Jurnal Penelitian Politik, 6(1), 21-32. https://doi.org/10.14203/jpp. v6i1.519 